
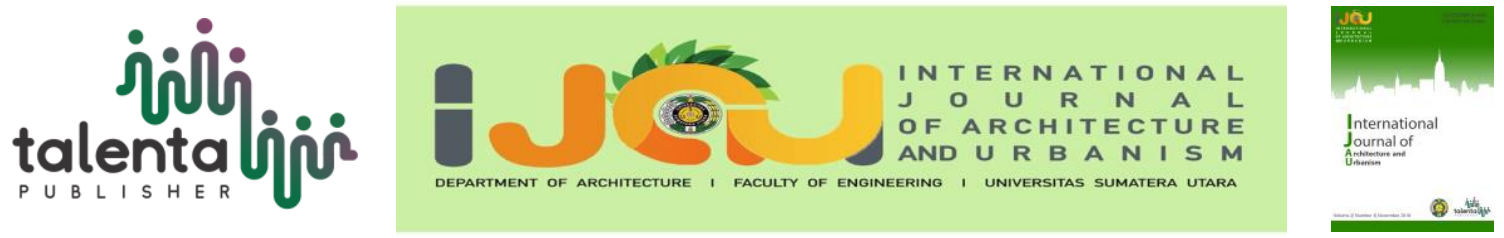

\title{
Designing a Culinary Village With Eco-Architecture Approach in Kampung Badur
}

\author{
Dwira Nirfalini Aulia ${ }^{1 *}$, Namira Sani ${ }^{1}$ \\ ${ }^{1}$ Architecture Department, Faculty of Engineering, Universitas Sumatera Utara, Medan, Indonesia
}

\begin{abstract}
Based on data from Dinas Perumahan dan Permukiman Kota Medan, Kampung Badur is one of housings and settlements with very poor slum level. This statement is constituted by irregular home plots, disobedience to house building regulations, and uninhabitable physical condition of buildings and environments but Kampung Badur also has some potential in social, economic and cultural aspects that can be developed. Looking at the situations in Kampung Badur, this area needs to be rearranged into a better area by exploiting the existing potential to become a commercial area like culinary area, designing decent residential model, adding facilities and public spaces.
\end{abstract}

Keyword: Commercial, culinary, housing, settlement

\section{Introduction}

Kampung Badur is a settlement which located on the outskirts of the Deli River in Hamdan Subdistrict Medan Maimun District, Medan. The river basin area serves as a place for unplanned settlements. The orientation of settlements in Kampung Badur is influenced by the Deli river flow along the area. The increasing demand for shelter makes the riverbanks a target for people to occupy. Thus, the need is realized by building residential areas in places that should not be built settlements such as river banks. Hamdan Subdistrict precisely Kampung Badur is one of housing and slums with very poor slum level [1]. Based on RTRW (Region Spatial Plans) Medan City 2008-2028, Kampung Badur should have 15 meters of Gass Line, $25 \%$ Green Coefficient $(\mathrm{KDH})$, but in reality, Kampung Badur did not implement the regulation. Also, the environment condition of Kampung Badur which is often affected by the flood and the unavailability of garbage dumping site and the physical form of the building which use the untreated secondhand materials, the lack of air and the incoming lighting make this settlement called unfit for habitation. Looking at the existing problems in Kampung Badur this area needs to be reorganized so that it becomes a better area by exploiting the potentials.

*Corresponding author at: Department of Architecture, Faculty of Engineering, Universitas Sumatera Utara, Jalan Perpustakaan, Gedung J07, Medan, 20155, Indonesia

E-mail address: dwira_aulia@yahoo.com 


\section{Literatur Review}

The settlement comes from the word housing and the word human settlement which means settlement. This gives an impression of settlers and their attitudes and behavior in the environment, so it focuses on something that is not physical or inanimate such as a human. The slum is a general impression or picture of poor attitudes and behavior seen from low-income and standard of living level. According to the social sciences dictionary, slum areas are defined as a dirty area whose buildings are very unqualified. So the slum's area can be interpreted as an area occupied by people with low economic status and their housing buildings are not qualified to be called healthy housing.

The definition of slums based on their characteristics is an environment that has degraded [2]. In other words deteriorate both physically, economically and socially and does not allow the achievement of a decent life even tends to harm to its inhabitants. According to Diana, the characteristics of slums are settlements with very high occupancy and building density, irregular buildings, very poor house quality. Moreover, inadequate infrastructure and basic facilities such as drinking water, roads, wastewater, and garbage.

\section{Methodology}

The selection of project sites related to the issue of low-income housing problems in urban dwellings is slum area, then conducted a review through the literature of urban structures with slum areas in the city of Medan. The relevance of the slum category that has been determined by PEMKO Medan is then reviewed with the submission of several places to the supervisor. The selection of approved sites is then confirmed, is it true that the location is a slum settlement and what factors and causes of the slums are formed. The location is then linked with the characteristic of slum settlements by performing a social mapping method.

\section{Result and Discussion}

Existing site conditions are densely populated settlements located just behind the PT. Perkebunan Nusantara IV with a total land area of about 2.7 ha. The number of residents who occupy this location is 221 families with the total number of residents 1037 inhabitants. The number of people becomes a problem because it is not proportional to the area so that there needs to be rearrangement by making the settlement of the residents who formerly horizontally become vertical. However, because this location is in the center of the city and surrounded by commercial buildings, then it can also be a potential to support the economic activities of residents. Social aspect at this designing location is marked by social interaction conducted on the terrace of houses and stalls in this area. The social interaction of children is to play and bathe in the river (Figure 1). For deliberation, activities are usually done in a spacious room such as in the education shelter or the head of neighborhood's house. 


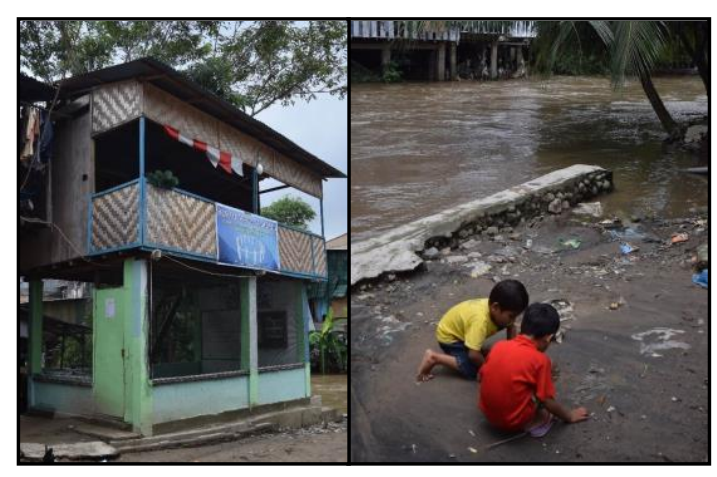

Figure 1. Education Shelter and Playing Area of Kampung Badur

Meanwhile, regarding the cultural community, the majority of the tribes that exist in this area is the Minang tribe. The reason is that the population who came to Kampung Badur on average influenced by communication from the community who had lived in advance in this location and then invite their family to reside. The livelihoods of various citizens are street vendors, satay vendors, meatball traders, parking attendants, heavers and others. The economic activities undertaken in this location are in the form of rice stalls, snack and coffee shops, and home industries that make cakes that are usually distributed to stalls. Seeing the economic condition of citizens who mostly work in the field of small business in the form of food, then this area can be a potential in improving the economy of society (Figure 2). This potential can be developed by providing a better container by building a culinary area.

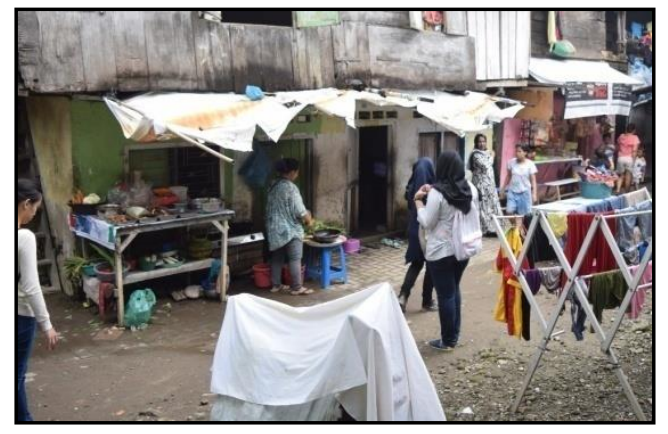

Figure 2. Economic Activity in Kampung Badur

In this scheme, an income-generating effort was made by creating additional resources without disrupting the primary income (Figure 3). Based on the research, $48 \%$ of Householders of Kampung Badur are interested in culinary, while those interested in urban farming and waste bank are estimated at $34 \%$ and $18 \%$. To run the organization, people who interested in urban farming will form a group called Badur Hijau. The yields will be vegetables and fruits which are the basic needs of the community. Profits from the sale of vegetables and fruits are then divided into members of the farmer group of Badur Hijau, North Sumatra Provincial Government, and capital for the next planting period. This system is also applied to the Waste Bank organization 


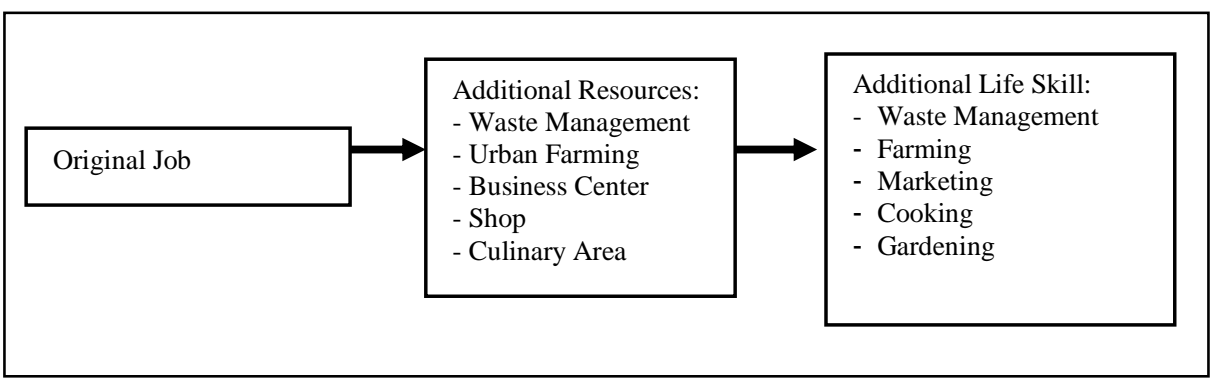

Figure 3. Scheme of Economic Activity of Kampung Badur

There is the design approach used aims to improve the quality of the environment regarding reducing the negative impact of development [3]. The application of Urban Farming is one way of implementing the ecological architecture design. Also, urban farming is placed in the culinary area so visitors can also see the urban landscape. Utilization of used material that serves as a container plant is also done to save costs and energy. In this concept, the building uses both local and second-hand materials that are recycled. It also aims to reduce costs and energy and not damage the existing ecosystem (Figure 4).

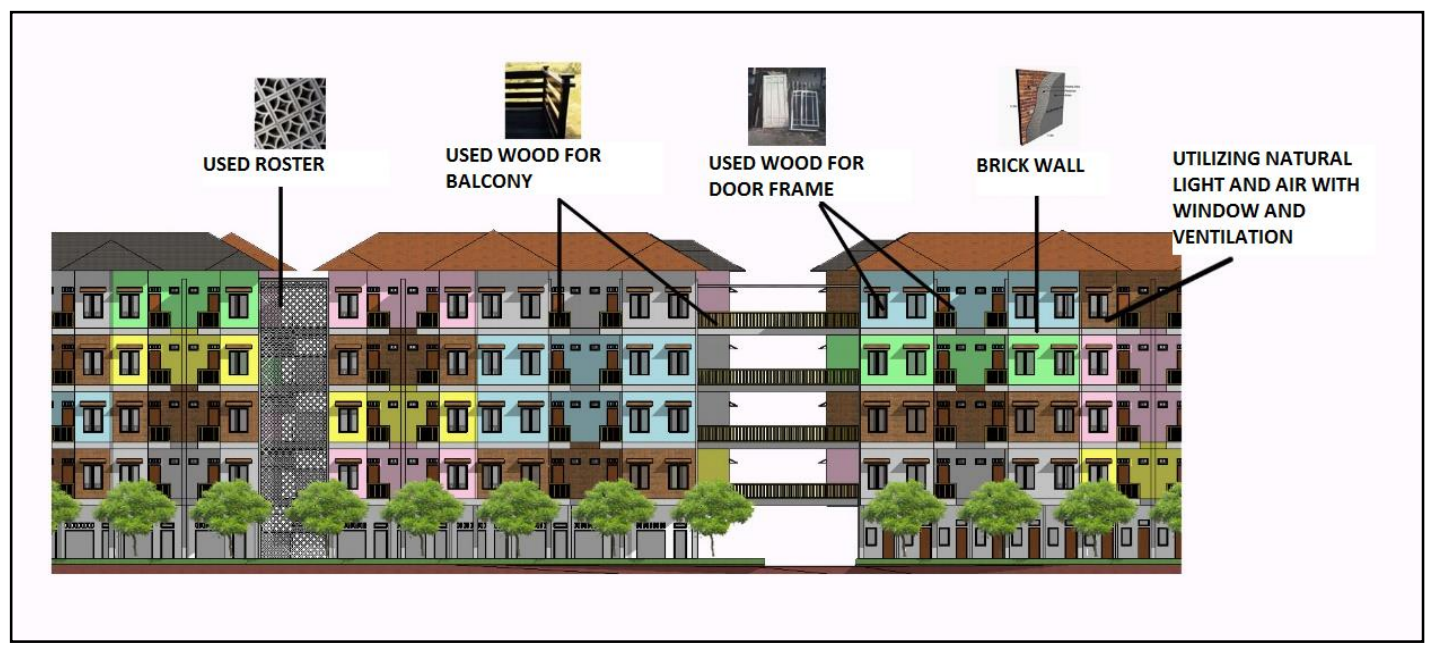

Figure 4. Application Of Local Materials

The rainwater in this building is recycled and reused as water for the garden so it can reduce the need for clean water. While the waste generated in this building is also recycled and reused into something useful like craft and fertilizer products. Moreover, the utilization of natural light and air conducted at Kampung Kuliner is by adding voids in the middle of the building, applying single corridor, the application of openings of windows and ventilation holes, and the application of vegetation (Figure 5). 


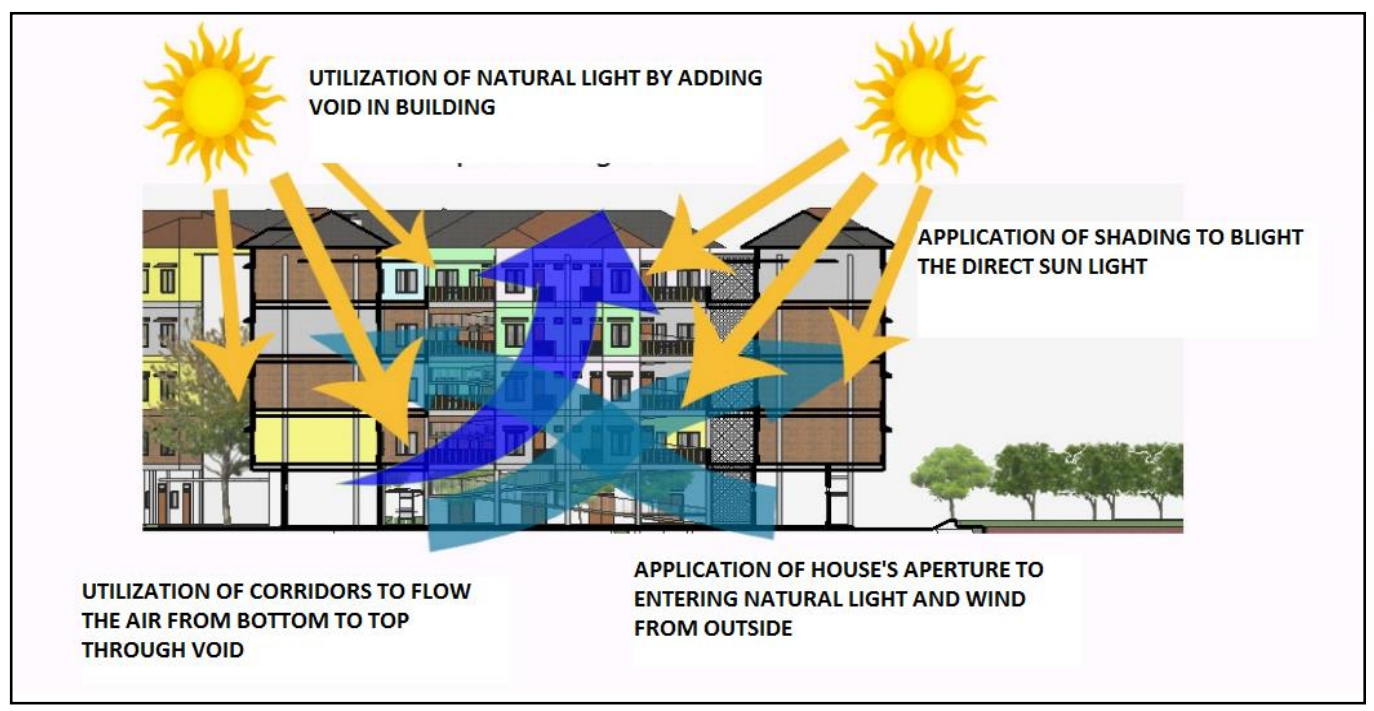

Figure 5. Natural Light and Air Application

The vegetation will be applied around the area as well as in the building. It has many purposes as shade, sunblock, air conditioning, pollutant and noise filters, and as aesthetics. As for the concept of bio pore on the ecological application is to make a hole recharge (LRB) at some point in the open area that has been planned and then fills it with organic waste. The location of the site on Jalan Badur is very efficient for the achievement of vehicles, public transportation, and truck because this road is flanked by a big road (Figure 6).

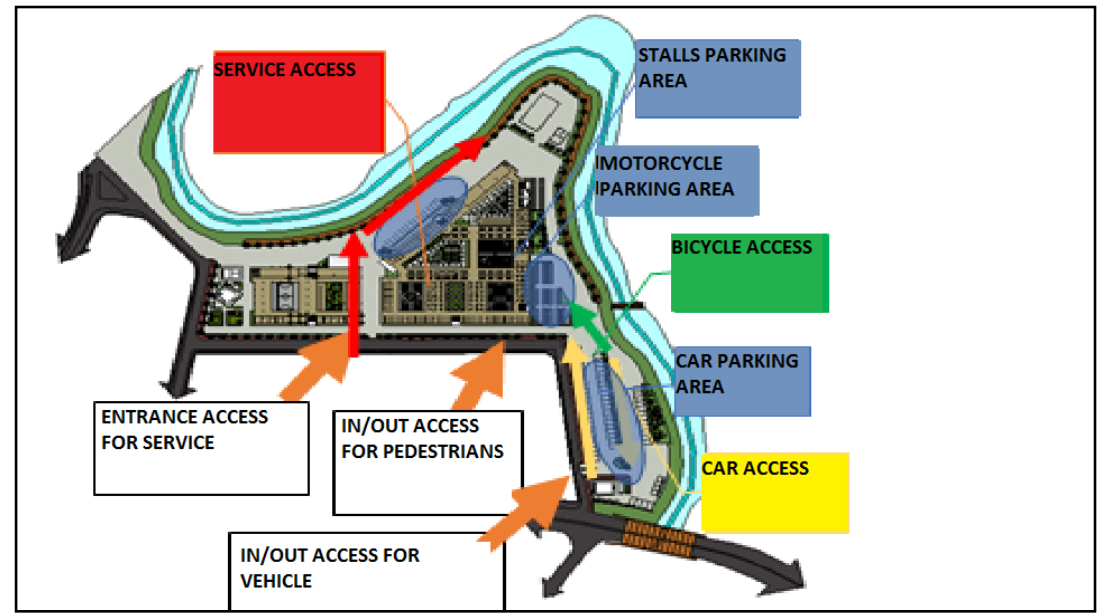

Figure 6. Landscape Planning

In this design, the concept of green governance in the area is divided into several areas, namely shared parks, playgrounds, urban farming, communal areas, pedestrian, parking and river line borders which will be used as jogging track and drainage arrangement (Table 1). 
Table 1. List of Plants That Are Applied

\begin{tabular}{llc}
\hline \multicolumn{1}{c}{ Type of Plants } & \multicolumn{1}{c}{ Name of Plants } & Production Results \\
\hline Vegetable Plants & - Red onion & $7,79 \mathrm{ton} / \mathrm{ha}$ \\
& - Cucumber & $13,63 \mathrm{ton} / \mathrm{ha}$ \\
& - Tomato & $20,70 \mathrm{ton} / \mathrm{ha}$ \\
& - Chili & $9,71 \mathrm{ton} / \mathrm{ha}$ \\
& - Lime leaves & $10 \mathrm{ton} / \mathrm{ha}$ \\
& - Leek & $7,16 \mathrm{ton} / \mathrm{ha}$ \\
\hline Herbal Plants & - Aloe vera & $3,27 \mathrm{~kg} / \mathrm{m}^{2}$ \\
& - Turmeric & $3,02 \mathrm{~kg} / \mathrm{m}^{2}$ \\
& - Kencur & $2,73 \mathrm{~kg} / \mathrm{m}^{2}$ \\
& - Galangal & $4,15 \mathrm{~kg} / \mathrm{m}^{2}$ \\
& - Ginger & $3,25 \mathrm{~kg} / \mathrm{m}^{2}$ \\
\hline Fruit Plants & - Jackfruit & $194,59 \mathrm{~kg} / \mathrm{tree}$ \\
& - Mango & $202,07 \mathrm{~kg} / \mathrm{tree}$ \\
& - Water apple & $82,68 \mathrm{~kg} / \mathrm{tree}$ \\
& - Carambola & $129,41 \mathrm{~kg} / \mathrm{tree}$ \\
\hline Shade Plants & - Tanjung Trees & - \\
\hline Pollutant and Noise & - Yellow Palms & - \\
Filter Plants & - Bougenville & - \\
& - Lidah mertua & - \\
\hline
\end{tabular}

Furthermore, many activities that need to be in the container to support the lifestyle of the residents by providing facilities in the culinary village and it does not only be used for residents but also users from outside (Figure 7).

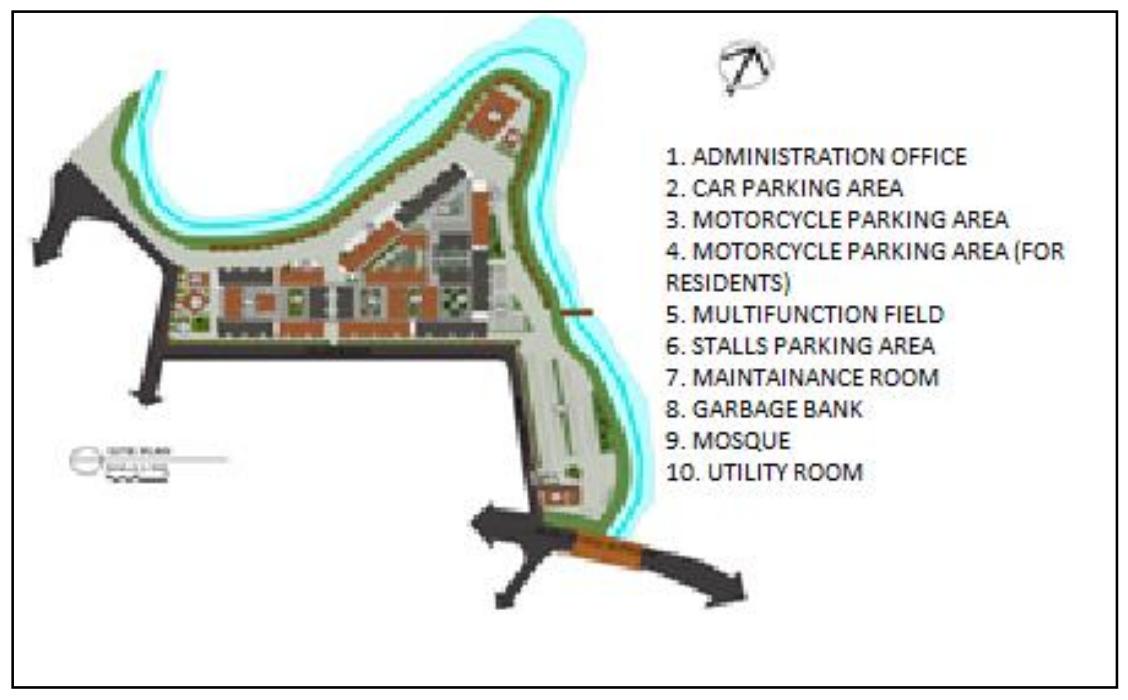

Figure 7. Outdoor Spatial Planning

In this building, the occupancy is on the 2nd-5th floor while on the 1st floor which is semipublic, is used as a shared facility such as multipurpose room, communal garden, playground, pre-study, medical center, culinary area and dwelling for disabled. And the service room is on corners on each floor. In residential units, each unit is given a balcony that can be used as a drying place. Also, each residential unit also added a terrace that is located in front of the dwelling; the addition is used to accommodate the habit of social interaction among residents commonly done in front of the house (Figure 8). 


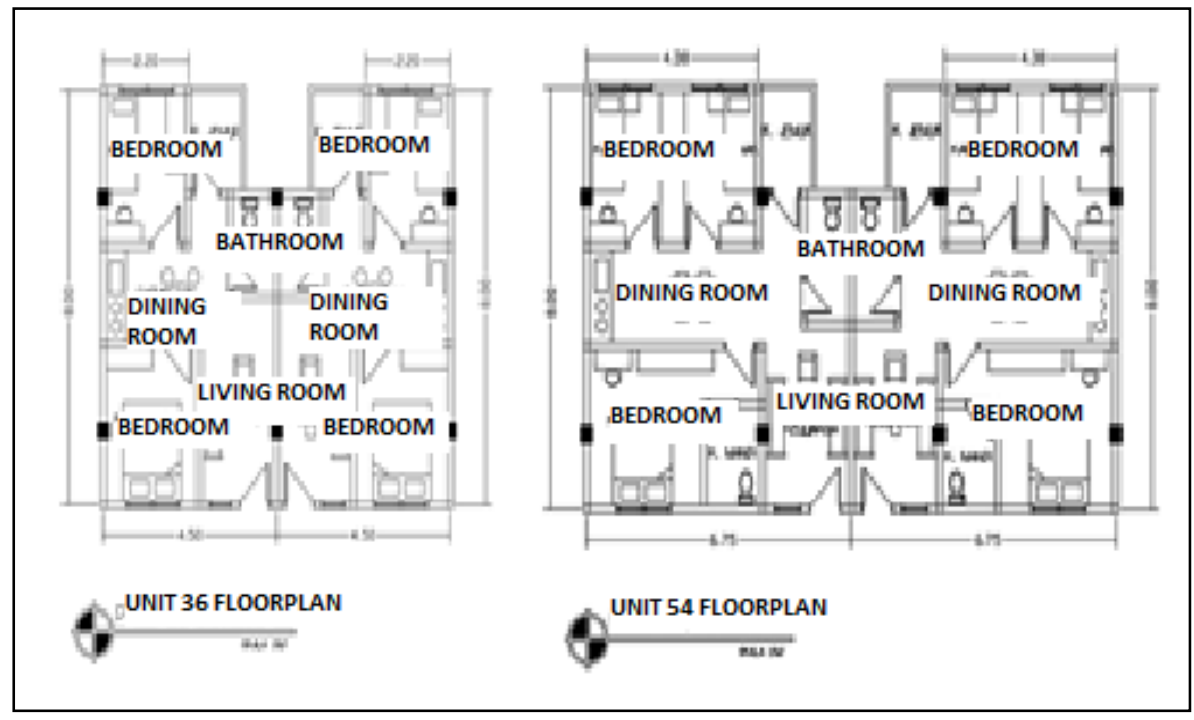

Figure 8. Dwelling Unit Detail

The concept of mass in this building is made by responding to the shape of the land and following the condition of the existing village which forms the different roof (Figure 9). Facades in the Kampung Badur is also designed with colors to make it look more attractive and more adapted to the previous village circumstances that have different colors according to the identity of each occupant.

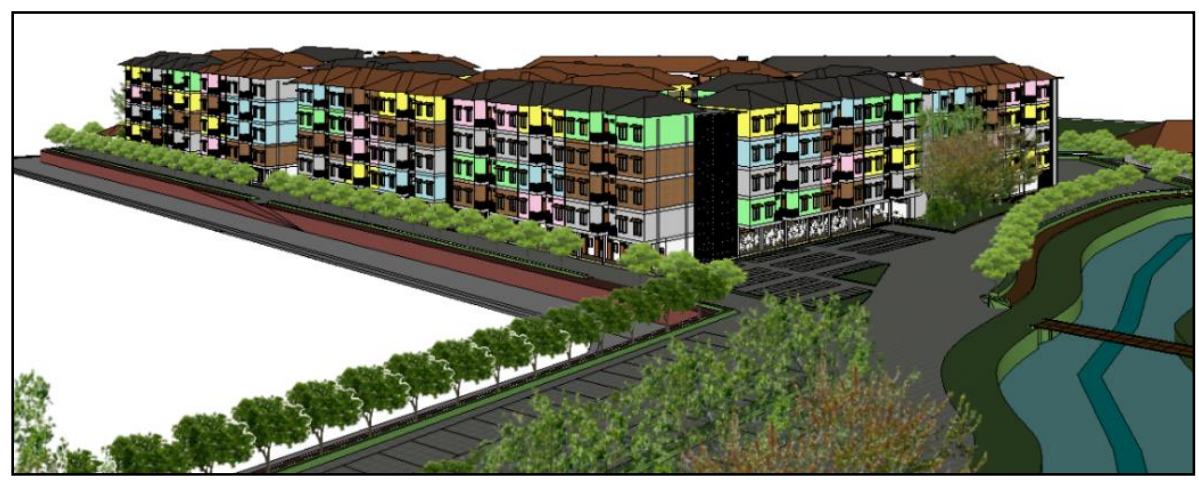

Figure 9. Façade and Mass Concept

The foundation to be used in this building is bored pile foundation. This bored pile foundation is very suitable to be applied to the Kampung Badur residential area located in a densely populated area because the construction process does not disturb the residents and the surrounding environment and can withstand larger loads. As for the upper structure, this building uses a rigid frame structure that can withstand forces in the vertical and horizontal direction. With this structure can be arranged layout of spaces in a more efficient and flexible. To work faster, cheaper and reduce the required energy then this structure using a grid module that is $4.5 \mathrm{~m} x$ $4.5 \mathrm{~m}$. Utilization of ecological vertical housing, there is three utilization applied [4]. First, water supply system. Clean water comes from the PDAM; the water is stored in a container that is located in the building and then flowed through the pump to some communal water tanks located at the top of the building. As for the distribution system applying a down feed system 
that utilizes the earth's gravity and flowed to each dwelling based on the division specified. Secondly, for wastewater management, Blackwater is accommodated in the hole and then distributed to the waste treatment basin (STP). In this STP mud and water that has been safely removed from chemicals is channeled into public channels and sludge is drained.

As for the grey water coming from the sink, the waste of the used laundry flows to the control basin than to the STP (Sewage Treatment Plant) located on the 1st floor and higher than the flumes. Handling waste in this building using a gravity chimney system. There is one final waste collection site on each floor, where it is shaped like a vertical shaft continuously from the ground floor to the top floor. The gravity shaft measures 2.4 meters. In this building, there is also a garbage bank that can help residents in improving their economy by distributing waste to waste banks. Garbage obtained through an organic waste bank is processed into fertilizer, fish feed, and bio pore while nonorganic waste is into handicrafts and potted plants. Rainwater management in this building is treated the same as wastewater. Where rainwater flowed from the roof to the Rainwater Tank through the gutter of water than processed into water spray plants. The system activities by traders and visitors in the culinary area are the same as the system at foodcourt where they can order various foods with payment system at the same time at the cashier. The merchant's place of sale is consisted of permanent and non-permanent (Figure 10).

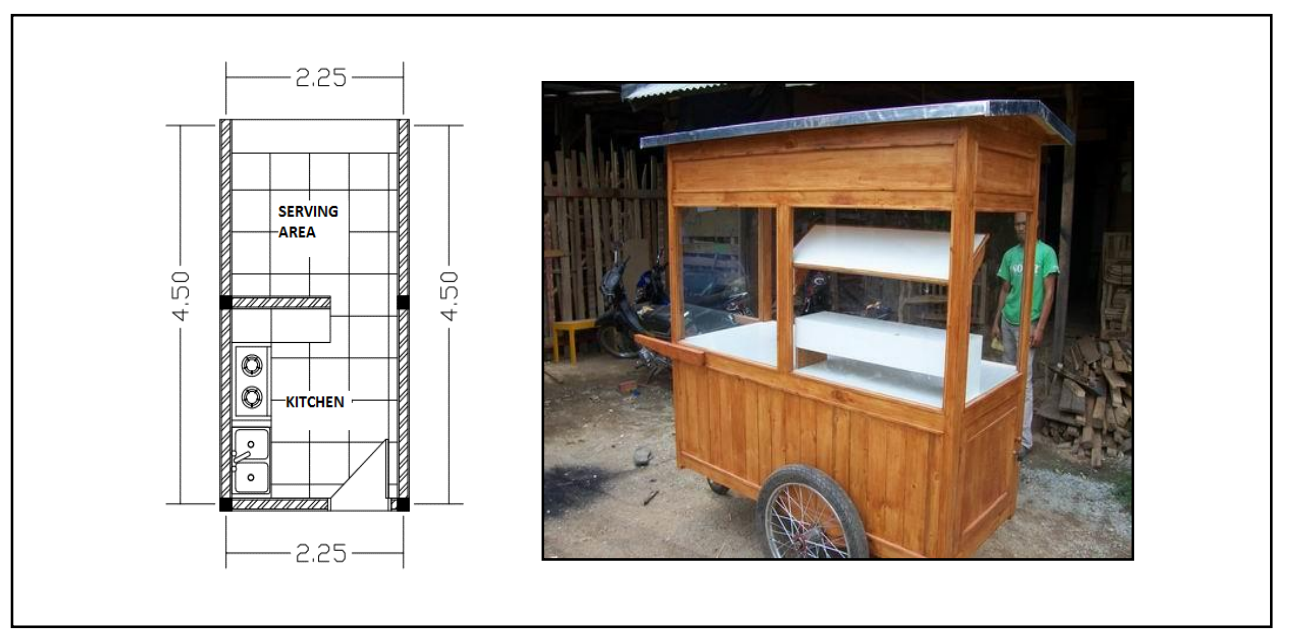

Figure 10. Cart dan Layout of Culinary Area

The organization structure that manages the culinary area is called UPKK (Culinary Activity Management Unit) at the community level whose members consist of people who have an interest in managing and driving culinary activities. UPKK is responsible for managing all the needs and activities in the culinary village which includes the management of income and expenditure of culinary activities and set the procurement of purposes used for culinary (Figure $11)$. 


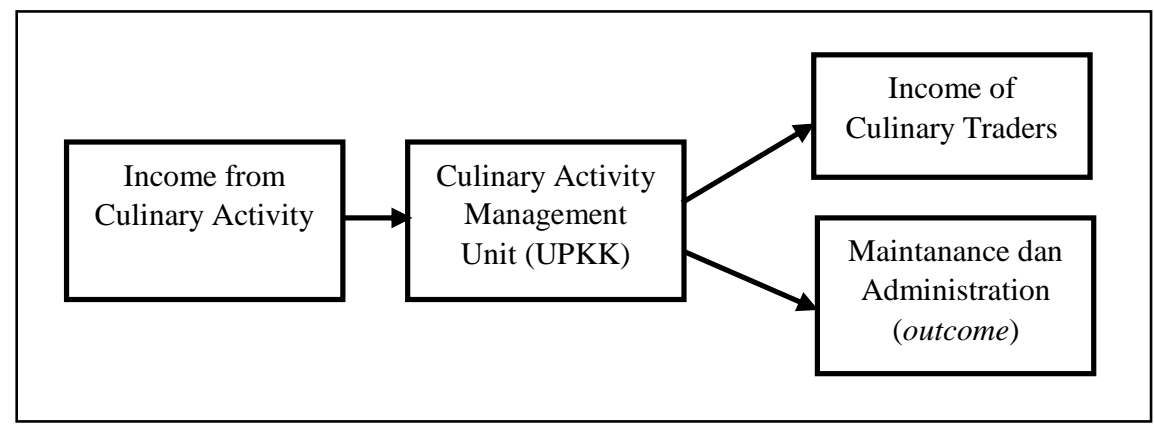

Figure 11. UPKK Activity Scheme

\section{Conclusion}

Based on the results of the discussion then it can be concluded that the concept of a dwelling by the needs of Kampung Badur community is designing Kampung Badur into a culinary village. The design is equipped with culinary trade area, urban farming, and garbage bank to improve people's economy. Besides, the facilities are provided in the form of multipurpose room, prelearning education space like PAUD, clinic, and kitchen together that can accommodate the social and cultural activities of Kampung Badur community. The culinary village is designed to the standard of healthy homes in each residential unit by applying ecological architectural designs such as urban farming in a residential environment by utilizing local materials, using natural light and air, maximal vegetation utilization and bio pore system. Waste of rainwater and garbage is processed so that it can be reused. It is expected that with the design of this culinary village with the approach of ecological architecture, Kampung Badur people can improve their quality of life with healthy dwelling and their economic life through the facilities that have been provided.

\section{Acknowledgment}

This research is part of the requirement to obtain a bachelor's degree in engineering.

\section{REFERENCES}

[1] D.S. Lubis, Strategi Pembangunan Perumahan dan Permukiman untuk Mengatasi Masalah Permukiman Kumuh di Kota Medan. Medan, Indonesia, 2016.

[2] D. Puspitasari. (2010) Portal Resmi Pemerintahan Kota Depok. [Online]. www.depok.go.id

[3] H. Frick, Dasar-dasar arsitektur ekologis (Vol. 1).: Kanisius, 2007.

[4] D. Purwanto and Yayi Asriandrie Ronim Azizah, Rumah Vertikal Ekologis di Surakarta dengan Fasilitas Pemberdayaan Ekonomi, Sosial dan Budaya Masyarakat Berpenghasilan Rendah. Surakarta, 2016. 